\title{
Protease Complex Reduces Potentially Pathogenic Microbial Populations in the Ileum While Optimizing Performance of Broiler Chickens
}

\author{
Mohiuddin Amirul Kabir Chowdhury ${ }^{1}$, Amrita Kumar Dhara ${ }^{2}$, Shivaji Dey ${ }^{2}$, Anirvid Sarkar ${ }^{2}$, \\ Sudipto Haldar², Glenmer Bathan Tactacan ${ }^{1, *}$ \\ ${ }^{1}$ Jefo Nutrition Inc., Saint-Hyacinthe, Canada \\ ${ }^{2}$ Agrivet Consultancy P Ltd., Kolkata, India
}

Email address:

gtactacan@jefo.ca (G. B. Tactacan)

${ }^{*}$ Corresponding author

\section{To cite this article:}

Mohiuddin Amirul Kabir Chowdhury, Amrita Kumar Dhara, Shivaji Dey, Anirvid Sarkar, Sudipto Haldar, Glenmer Bathan Tactacan. Protease Complex Reduces Potentially Pathogenic Microbial Populations in the Ileum While Optimizing Performance of Broiler Chickens. Animal and Veterinary Sciences. Vol. 9, No. 1, 2021, pp. 16-23. doi: 10.11648/j.avs.20210901.13

Received: February 3, 2021; Accepted: March 13, 2021; Published: March 17, 2021

\begin{abstract}
A 42-day trial was conducted to assess the effects of a dietary protease on growth performance and ileum population of selected bacteria in broiler chickens fed standard diets and diets deficient in crude protein and digestible amino acids (CP/AA, $\sim 5 \%$ ) or apparent metabolizable energy (AME, $50 \mathrm{kcal} / \mathrm{kg}$ ) or both. Reducing CP/AA and AME negatively affected average daily weight gain (ADG, $P<0.05$ ) and feed conversion ratio (FCR, $P<0.05)$. Dietary protease improved BW at 42-d $(P=0.021$, linear effect) of birds fed both standard and nutrient deficient diets but improved FCR $(P=0.0002)$ was only observed when supplemented to the standard diet. Serum protein concentration was not affected by the level of CP/AA and AME but decreased linearly with the level of protease $(P=0.02)$. Numbers of Escherichia coli, Salmonella spp. and Clostridium perfringens increased $(P=0.0001)$ with the decrease of dietary $\mathrm{CP} / \mathrm{AA}$ and AME. In contrast, the numbers of studied bacteria linearly decreased $(P=0.0001)$ with dietary protease level. Dietary protease was found to decrease the numbers of Clostridium perfringens $(P=0.0001)$ when supplemented to either low $\mathrm{CP} / \mathrm{AA}$ or low AME diets. It can be concluded that protease supplementation sustained the harvesting biomass in the experimental birds fed lower nutrient density diets and decreased the numbers of resident bacteria in the hind gut, some of which might be potential pathogens. Hence, the study documented not only the nutrient sparing effects but also the extra-proteinaceous effect in terms of gut health of dietary protease in broiler chickens.
\end{abstract}

Keywords: Protease, Amino Acids, Growth Performance, Microbiota, Broiler

\section{Introduction}

The modern broiler chickens are always vulnerable to impaired nutrient digestion, dysbacteriosis, cocci challenges, and exposure to Clostridium perfringens resulting in poor gut health and production performance. Previously, endogenous proteases were deemed to be sufficient for feed protein digestion $[1,2]$ despite the possibility of a considerable amount of undigested dietary protein reaching the hind gut [3-6]. Apajalahti and Vienola [7] are of the opinion that the microbiota residing inside the small intestine compete with the host for dietary AA. The competition is less in the proximal part of the small intestine, where the density of microbiota is low. The further down the intestine the AA move, the more likely it is that they will be utilized by intestinal bacteria making them completely unavailable to the host. Clostridium perfringens, the causative agent of necrotic enteritis, is not an exception to this rule [8]. They flourish as the quantity of protein that escapes intestinal digestion increases. To avoid the conundrum, rapid digestion of dietary proteins and uptake of AA in the proximal intestine is preferred. However, even with the highest quality of diet, it is not possible for the host to 
capture all the AA in the proximal intestine and passage of undigested AA to the hind gut is inevitable. Cowieson and Roos [9] suggested that exogenous protease should improve apparent ileal AA digestibility irrespective of the diet composition. A greater impact is likely if the inherent digestibility of the diet involved is on the lower side $(<90 \%)$ of the curve.

It is intriguing that the extra-proteinaceous effects elicited by exogenous protease are not being discussed at length in literature as did the protein sparing effects. The latter depend on the inherent digestibility of the basal diet and thus giving inconsistent outcomes while the former yields a more consistent and discernible effect. Several studies reported 2-10\% increase in apparent crude protein digestibility in animals fed diets supplemented with protease [6, 10-14]. Increase in digestible proteins and amino acids in the diets should limit the supply of undigested proteins to the hind gut eliciting a "starvation effect" on the bacteria residing in the hind gut. Supplementing a "low" protein diet with a protease should not only help in terms of cost savings but should also result in a better gut health.

The purpose of this study was to explore the effects of an exogenous multi-component alkaline protease in corn-soybean meal-based diets. The diets were formulated either adequately as per commercial standard or were deficient in CP/AA or AME or both. The hypothesis was that exogenous protease would improve the $\mathrm{N}$ utilization irrespective of adequate or reduced $\mathrm{CP} / \mathrm{AA}$ levels. By virtue of its effects on energy metabolism, it will spare dietary AME to sustain performance even with diets of lower nutrient density. It was further hypothesised that lower $\mathrm{CP} / \mathrm{AA}$ or/and AME in diet would reduce available nutrient to the hind gut and hence would limit bacterial proliferation.

\section{Materials and Methods}

The protocol used in this study was reviewed and approved by the Institutional Animal Ethics Committee of the Research Station to ensure that no violation of the existing ethical rules takes place at any stage during the experiment.

\subsection{Experimental Design and Diets}

A $2 \times 2 \times 3$ factorial design with two levels of dietary CP/AA (standard and reduced by 5\%), two levels of AME (standard and reduced by $50 \mathrm{kcal} / \mathrm{kg}$ ) and three levels of dietary protease $(0,125$, and $200 \mathrm{~g} / \mathrm{t})$ was used in this study. The details of the diet composition and their nutritive values are described in Tables 1 and 2, respectively.

Table 1. Ingredient composition of the basal diets $(\mathrm{g} / \mathrm{kg})$.

\begin{tabular}{|c|c|c|c|c|c|c|c|c|c|c|c|c|}
\hline \multirow{2}{*}{ Ingredients } & \multicolumn{4}{|c|}{ Starter } & \multicolumn{4}{|c|}{ Grower } & \multicolumn{4}{|c|}{ Finisher } \\
\hline & STD & $\mathbf{L P}$ & $\mathbf{L E}$ & LP-LE & STD & LP & LE & LP-LE & STD & LP & $\mathbf{L E}$ & LP-LE \\
\hline Corn & 594.0 & 615.0 & 606.0 & 630.0 & 615.0 & 637.0 & 627.0 & 650.0 & 641.0 & 670.0 & 654.0 & 680.0 \\
\hline Soybean meal ${ }^{1}$ & 340.0 & 321.0 & 338.0 & 319.0 & 312.0 & 294.0 & 310.0 & 290.0 & 280.0 & 255.0 & 276.0 & 254.0 \\
\hline De-oiled rice bran ${ }^{2}$ & 10.0 & 10.0 & 10.0 & 10.0 & 10.0 & 10.0 & 10.0 & 10.0 & 10.0 & 10.0 & 10.0 & 10.0 \\
\hline Rice bran oil ${ }^{3}$ & 17.3 & 13.2 & 7.5 & 3.5 & 29.0 & 25.5 & 19.0 & 15.9 & 38.0 & 33.9 & 28.8 & 25.0 \\
\hline Dicalcium phosphate & 19.4 & 19.4 & 19.4 & 19.3 & 17.4 & 17.3 & 17.3 & 17.4 & 14.5 & 14.5 & 14.6 & 14.5 \\
\hline Limestone powder & 5.3 & 8.2 & 5.4 & 5.4 & 3.7 & 3.7 & 3.7 & 3.8 & 3.5 & 3.5 & 3.5 & 3.5 \\
\hline DL-methionine & 2.6 & 2.3 & 2.6 & 2.2 & 2.5 & 2.3 & 2.5 & 2.3 & 2.4 & 2.2 & 2.4 & 2.2 \\
\hline L-lysine $\mathrm{HCl}$ & 2.1 & 1.8 & 2.1 & 1.8 & 1.7 & 1.7 & 1.7 & 1.7 & 1.5 & 1.8 & 1.6 & 1.7 \\
\hline L-threonine & 0.7 & 0.5 & 0.7 & 0.5 & 0.6 & 0.7 & 0.7 & 0.8 & 1.0 & 1.0 & 1.0 & 1.0 \\
\hline Salt & 2.5 & 2.5 & 2.5 & 2.5 & 2.0 & 2.0 & 2.0 & 2.0 & 2.0 & 2.0 & 2.0 & 2.0 \\
\hline Trace minerals ${ }^{4}$ & 0.5 & 0.5 & 0.5 & 0.5 & 0.5 & 0.5 & 0.5 & 0.5 & 0.5 & 0.5 & 0.5 & 0.5 \\
\hline Choline chloride 60 & 1.0 & 1.0 & 1.0 & 1.0 & 1.0 & 1.0 & 1.0 & 1.0 & 1.0 & 1.0 & 1.0 & 1.0 \\
\hline Growth promoter ${ }^{5}$ & 0.5 & 0.5 & 0.5 & 0.5 & 0.5 & 0.5 & 0.5 & 0.5 & 0.5 & 0.5 & 0.5 & 0.5 \\
\hline Vitamin premix & 0.5 & 0.5 & 0.5 & 0.5 & 0.5 & 0.5 & 0.5 & 0.5 & 0.5 & 0.5 & 0.5 & 0.5 \\
\hline Toxin binder & 1.0 & 1.0 & 1.0 & 1.0 & 1.0 & 1.0 & 1.0 & 1.0 & 1.0 & 1.0 & 1.0 & 1.0 \\
\hline Coccidiostat $^{6}$ & 0.5 & 0.5 & 0.5 & 0.5 & 0.5 & 0.5 & 0.5 & 0.5 & 0.5 & 0.5 & 0.5 & 0.5 \\
\hline Phytase $^{7}$ & 0.1 & 0.1 & 0.1 & 0.1 & 0.1 & 0.1 & 0.1 & 0.1 & 0.1 & 0.1 & 0.1 & 0.1 \\
\hline TOTAL & 1000 & 1000 & 1000 & 1000 & 1000 & 1000 & 1000 & 1000 & 1000 & 1000 & 1000 & 1000 \\
\hline
\end{tabular}

$\mathrm{STD}=$ standard diet, $\mathrm{LP}=$ low $\mathrm{CP} / \mathrm{AA}$ diet (density decreased by $5 \%$ from the $\mathrm{STD}), \mathrm{LE}=$ low AME diet (ME decreased by $50 \mathrm{kcal} / \mathrm{kg}$ from the $\mathrm{STD}$ ), LP/LE $=$ both $\mathrm{CP} / \mathrm{AA}$ and $\mathrm{AME}$ was by $5 \%$ and $50 \mathrm{kcal} / \mathrm{kg}$ respectively from the STD.

${ }^{1}$ Contained $49.4 \%$ crude protein; ${ }^{2}$ Added to adjust the premix volume and the protease was added through replacement of an equivalent amount; ${ }^{3} \mathrm{ME}$ at $1-14 \mathrm{~d}=$ $8500 \mathrm{kcal} / \mathrm{kg}$ and at $15-42 \mathrm{~d}=8900 \mathrm{kcal} / \mathrm{kg} ;{ }^{4}$ Yeast protein complexes of copper, iron, manganese, zinc, selenium and chromium; ${ }^{5} \mathrm{Bacitracin}$ methylene di-salicylate $(10 \mathrm{mg} / \mathrm{kg}) ;{ }^{6}$ Salinomycin $12 \% ;{ }^{7}$ Advanced Escherichia coli phytase with a declared activity of $5000 \mathrm{FTU} / \mathrm{g}$ of the product. 
Table 2. Calculated (unless stated otherwise) chemical composition and essential amino acid profile of the basal diets ( $\mathrm{g} / \mathrm{kg}$ ).

\begin{tabular}{|c|c|c|c|c|c|c|c|c|c|c|c|c|}
\hline \multirow{2}{*}{ Ingredients } & \multicolumn{4}{|c|}{ Starter } & \multicolumn{4}{|c|}{ Grower } & \multicolumn{4}{|c|}{ Finisher } \\
\hline & STD & $\mathbf{L P}$ & $\mathbf{L E}$ & LP-LE & STD & $\mathbf{L P}$ & $\mathbf{L E}$ & LP-LE & STD & LP & LE & LP-LE \\
\hline $\mathrm{AME} \mathrm{kcal} / \mathrm{kg}$ & 2900 & 2900 & 2850 & 2850 & 3000 & 3000 & 2950 & 2950 & 3100 & 3100 & 3050 & 3050 \\
\hline Crude Protein (analyzed) & 222.0 & 207.9 & 222.0 & 209.0 & 217.0 & 203.0 & 213.0 & 203.1 & 197.0 & 187.0 & 197.0 & 187.2 \\
\hline Available P (analyzed) & 4.8 & 4.8 & 4.8 & 4.8 & 4.5 & 4.5 & 4.5 & 4.5 & 4.0 & 4.0 & 4.0 & 4.0 \\
\hline Fibre (analyzed) & 28.2 & 26.9 & 26.8 & 28.8 & 25.3 & 25.7 & 25.3 & 24.5 & 25.4 & 24.5 & 23.9 & 24.5 \\
\hline Fat (analyzed) & 47.6 & 45.5 & 30.4 & 30.0 & 59.8 & 61.3 & 49.6 & 43.6 & 66.8 & 67.2 & 58.4 & 53.9 \\
\hline Chloride & 24.0 & 24.0 & 24.0 & 24.0 & 22.0 & 22.0 & 22.0 & 22.0 & 22.0 & 22.0 & 22.0 & 22.0 \\
\hline Potassium & 98.0 & 95.0 & 93.0 & 95.0 & 92 & 89.5 & 92.7 & 89.5 & 86.5 & 82.1 & 86.4 & 82.1 \\
\hline Choline & 1.80 & 1.78 & 1.68 & 1.79 & 1.76 & 1.72 & 1.76 & 1.72 & 1.68 & 1.63 & 1.68 & 1.63 \\
\hline \multicolumn{13}{|l|}{ Digestible amino acids } \\
\hline Lysine & 12.5 & 11.8 & 12.5 & 11.8 & 11.5 & 11.0 & 11.5 & 11.0 & 10.5 & 10.0 & 10.5 & 10.0 \\
\hline Methionine & 4.6 & 4.4 & 4.6 & 4.4 & 4.4 & 4.2 & 4.4 & 4.2 & 4.2 & 4.0 & 4.2 & 4.0 \\
\hline Met + Cys & 8.8 & 8.3 & 8.8 & 8.3 & 8.4 & 8.0 & 8.4 & 8.0 & 8.0 & 7.6 & 8.0 & 7.6 \\
\hline Threonine & 8.0 & 7.6 & 8.0 & 7.6 & 7.6 & 7.3 & 7.6 & 7.3 & 7.4 & 7.0 & 7.4 & 7.0 \\
\hline Arginine & 13.2 & 12.4 & 13.2 & 12.4 & 12.4 & 11.8 & 12.4 & 11.8 & 11.6 & 11.0 & 11.6 & 11.0 \\
\hline Isoleucine & 8.4 & 7.9 & 8.4 & 7.9 & 7.9 & 7.6 & 7.9 & 7.6 & 7.5 & 7.1 & 7.5 & 7.1 \\
\hline Valine & 9.5 & 9.2 & 9.5 & 9.2 & 9.0 & 8.7 & 9.0 & 8.7 & 8.4 & 8.0 & 8.4 & 8.0 \\
\hline
\end{tabular}

$\mathrm{STD}=$ standard diet, $\mathrm{LP}=$ low protein/AA diet (density decreased by $5 \%$ from the STD), LE = low energy diet (ME decreased by $50 \mathrm{kcal} / \mathrm{kg}$ from the STD), $\mathrm{LP} / \mathrm{LE}=$ both protein/AA and ME was by $5 \%$ and $50 \mathrm{kcal} / \mathrm{kg}$, respectively, from the STD.

A flock of 720 male Cobb broiler chickens (12 treatments $x$ 6 replicates $\mathrm{x} 10$ birds per replicate) was raised for a period of $42 \mathrm{~d}$ with corn-soybean meal-based diets. Four corn-soybean meal-based basal diets were formulated for the experiment. These are: 1) Standard (STD) diet, with adequate $\mathrm{CP} / \mathrm{AA}$ and AME; 2) A low protein (LP) diet, where CP/AA was decreased by $5 \%$; 3 ) A low energy (LE) diet, where dietary AME was decreased by $50 \mathrm{kcal} / \mathrm{kg}$; and 4) A low protein-low energy (LP-LE) diet, where both dietary CP/AA and AME were decreased as mentioned above.

All four basal diets were supplemented with graded level $(0$, 125 , and $200 \mathrm{~g} / \mathrm{t}$ ) of a multi-component alkaline serine protease (Jefo Nutrition Inc., Quebec, Canada). The protease complex is derived from fermentation extracts of a naturally present novel bacterium where one protease unit (PROT) hydrolyses azocasein to produce an absorbance at $440 \mathrm{~nm}$ equivalent to the action of one unit of a standard protease assayed under identical conditions

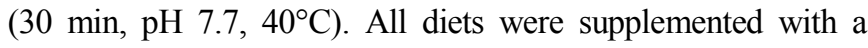
phytase ( $\mathrm{AB}$ Vista, Marlborough, UK) with defined phytase activity of $5000 \mathrm{FTU} / \mathrm{kg}$. The matrix contribution from the phytase of calcium $(0.165 \%)$, available $\mathrm{P}(0.15 \%)$ and sodium $(0.035 \%)$ were added in diet formulation.

\subsection{Husbandry and Performance Traits}

The experimental chicks, procured from a local hatchery, were assigned to one of the 12 dietary treatments following a randomized block design (RBD). A pen (1.2 m x $1.2 \mathrm{~m}$ ) was used as an experimental unit where the litter was made of wood shavings and ground straw. The birds were fed a starter (1-14 d), a grower (15-28 d), and a finisher (29-42 d) diet ad libitum with unrestricted supply of drinking water. The diets were pelleted in a laboratory scale pellet mill $(100 \mathrm{~kg} / \mathrm{h}$ capacity $)$ at $82( \pm 2)^{\circ} \mathrm{C}$ temperature, $2.5 \mathrm{~kg} / \mathrm{cm}^{2}$ of steam pressure along with $30-35 \mathrm{sec}$ in the conditioner. All chicks received feed within $12 \mathrm{~h}$ of hatch and were exposed to continuous lighting during the first week and $20 \mathrm{~h}$ lighting from day 8 till harvesting. The birds were vaccinated against Infectious Bronchitis (Nobilis IB Ma5) at $0 \mathrm{~d}$ of age; Newcastle disease at 5 and $19 \mathrm{~d}$ of age through eye instillation with a freeze-dried vaccine virus strain (Nobilis ${ }^{\mathrm{TM}} \mathrm{ND}$ Clone 30) and Infectious Bursal disease (Nobilis ${ }^{\mathrm{TM}}$ IBD 228E). All three vaccines were acquired from MSD Animal Health, Massachusetts, USA.

Body weight (BW) was recorded weekly by pens at $0800 \mathrm{~h}$. A measured quantity of feed, was offered to each pens daily in two equal divisions and cumulative feed intake (FI) was calculated weekly by subtracting the quantity of feed left in each pen from the total quantity of the feed offered. Average daily body weight gain (ADG) and average daily feed intake (ADFI) were calculated for 1-14 d, 15-28 d, and 29-42 d. Feed conversion ratio (FCR) was calculated as a ratio between ADFI to ADG for each period. Mortality was recorded and the dead birds were weighed to adjust the data accordingly. Overall liveability was calculated for the cumulative period of 1-42 $\mathrm{d}$ and European Productivity Index (EPI) was calculated as: $\mathrm{EPI}=[(100-$ mortality $) \times($ mean BW/age $) \times 100] / F C R$.

\subsection{Analyses of Serum}

Whole blood samples were collected from one randomly selected bird from each pen ( 6 birds from each treatment) at $42 \mathrm{~d}$ of age. Birds were fasted overnight prior to the blood collection. Approximately $3 \mathrm{~mL}$ blood sample was collected from the right brachial veins in glass tubes with no anti-coagulant. The samples were kept in ambient temperature for clotting followed by transfer to ice boxes for serum separation. The serum was harvested and preserved in polystyrene tubes at $-20^{\circ} \mathrm{C}$ till they were analysed for glucose, total protein, and uric acid. Commercially available biochemical kits (Bhat Biotech P Ltd., Bengaluru, India for glucose and Mediclone Biotech P Ltd., Chennai, India for uric acid and total protein) were used for these analyses using photometric principles with a semi-automatic 
blood biochemistry analyser (RT-9200, Rayto Life and Analytical Sciences Co., Ltd, Shen Zhen, China). All samples were analysed in duplicate and results varying by more than $5 \%$ warranted re-analysis.

\subsection{Assessing Bacterial Population in Ileal Digesta}

At $42 \mathrm{~d}$, one bird was randomly selected per pen. The selected birds were mechanically stunned, manually slaughtered, and bled out. The carcass was washed repeatedly with sterile normal saline solution and then eviscerated. The small intestine and the caeca were manually separated from the rest of the carcass to collect the digesta present in ileum for the enumeration of Salmonella spp., Escherichia coli, and Clostridium perfringens [15]. After repeated washing with sterile phosphate buffer saline, the designated part of the ileum was opened with an incision, and the digesta were emptied into sterilized polystyrene tubes. The tubes were immediately stored at $4^{\circ} \mathrm{C}$ and within $24 \mathrm{~h}$, cultured in a nutrient broth. The culture solution was decimally diluted and then further cultured in ready-to-use media plates specific for the target organisms (Hi-Media Laboratories, Mumbai, India). All the cultures were incubated at $37^{\circ} \mathrm{C}$ for 36 to $48 \mathrm{~h}$ for the development of visible counts. For Clostridium perfringens count, the plates were incubated anaerobically for $48 \mathrm{~h}$ in the presence of $\mathrm{CO}_{2}$. All the visible colonies were counted in a colony counter and the values were expressed as $\log _{10}$ colony forming units $(\mathrm{CFU}) / \mathrm{g}$ of ileal digesta.

\subsection{Statistical Analyses}

All performance data (BW, ADG, ADFI, FCR, and EPI) were pooled by individual pens. For all other data, individual birds were considered as a single experimental unit. The data were analysed in the general linear model of SPSS (version 26.1) using a $2 \times 2 \times 3$ factorial design where the levels of dietary AME (standard and LE), CP/AA (standard and LP) and protease (0, 125 , and $200 \mathrm{~g} / \mathrm{t}$ ) were considered as the main effects. The main effects were separated and interactions between AME x Protease, $\mathrm{CP} / \mathrm{AA} \times$ Protease and AME $\mathrm{x}$ CP/AA $x$ Protease were determined. Polynomial contrast was applied on protease to check the linearity of dose response. The results were expressed as means and pooled standard error of means. A probability value of $P<0.05$ was considered to be statistically significant.

\section{Results}

The growth performance of broilers fed standard or low levels of CP/AA and AME supplemented with increasing concentrations of a protease complex is shown on Table 3 . In the present study, feeding LP or LE diets had no significant effect $(P>0.05)$ on the overall growth performance (ADG, ADFI, FCR, liveability, and EPI) of broiler chickens as compared to those fed the STD diet. Furthermore, feeding LP-LE diets resulted to significant losses $(P<0.05)$ in growth performance as indicated by a decrease in ADG (1-14 d, 15-28 d, 29-42 d, 1-42 d) and an increase in FCR (1-14 d) relative to birds on STD diets. The supplementation of protease, however, either at 125 or $200 \mathrm{~g} / \mathrm{t}$ on LP-LE diets allowed birds to recover the losses in growth performance.

The main and interaction effects of $\mathrm{CP} / \mathrm{AA}$, AME, and protease supplementation on indices of broiler growth performance are shown in Table 4 . The main effect of low dietary $\mathrm{CP} / \mathrm{AA}$ level was exhibited through losses in broiler performance as indicated by a significant decrease in ADG (at 29-42 $\mathrm{d}$ and 1-42 d), an increase in FCR (1-14 d, 15-28 d, 29-42 d, and 1-42 d), and a decrease in EPI as compared with broilers fed the STD diets. Similarly, broilers fed LE diets demonstrated a decrease in ADG (1-14 d, 15-28 d, and 1-42 d) and an increase in FCR (1-14 d, 15-28 d, 29-42 d, and 1-42 d), although, percentage liveability was increased as compared with broilers fed the STD diets. On the other hand, protease supplementation significantly improved ADG (15-28 d and 1-42 d), FCR (at 15-28 d), and EPI in a dose dependent linear pattern independent of the dietary $\mathrm{CP} / \mathrm{AA}$ and AME levels. A CP/AA x Protease interaction existed for ADG and ADFI (1-14 d), while an AME $x$ Protease interaction existed for ADG (1-14 d and 1-42 d), ADFI (1-42 d) and FCR (1-14 d). A 3 -way interaction effect among $\mathrm{CP} / \mathrm{AA}, \mathrm{AME}$, and Protease existed for ADFI at 1-42 d.

Table 3. Growth performance, livability and European productivity index (EPI) of broiler chicken fed standard (STD), low protein (LP), low energy (LE), and $L P-L E$ diets supplemented with graded level of a multi-component protease.

\begin{tabular}{|c|c|c|c|c|c|c|c|c|c|c|c|c|c|c|}
\hline \multirow[b]{2}{*}{ Treatments } & \multicolumn{4}{|c|}{ Average daily gain (g) } & \multicolumn{4}{|c|}{ Average daily feed intake (g) } & \multicolumn{4}{|c|}{ Feed conversion ratio } & \multirow{2}{*}{$\begin{array}{l}\text { Liveability } \\
\%\end{array}$} & \multirow[t]{2}{*}{ EPI } \\
\hline & $\begin{array}{l}1-14 \\
\text { d }\end{array}$ & $\begin{array}{l}15-28 \\
\text { d }\end{array}$ & $\begin{array}{l}29-42 \\
\text { d }\end{array}$ & $\begin{array}{l}1-42 \\
\text { d }\end{array}$ & $\begin{array}{l}1-14 \\
\text { d }\end{array}$ & $\begin{array}{l}15-28 \\
d\end{array}$ & $\begin{array}{l}29-42 \\
\text { d }\end{array}$ & $\begin{array}{l}1-42 \\
\text { d }\end{array}$ & $\begin{array}{l}1-14 \\
\text { d }\end{array}$ & $\begin{array}{l}15-28 \\
\text { d }\end{array}$ & $\begin{array}{l}29-42 \\
\text { d }\end{array}$ & $\begin{array}{l}1-42 \\
\text { d }\end{array}$ & & \\
\hline STD & $31.0^{\mathrm{bc}}$ & $70.4^{\mathrm{b}}$ & 109 & $70.3^{\mathrm{b}}$ & $39.6^{\mathrm{a}}$ & 115 & 191 & 115 & $1.28^{\mathrm{a}}$ & $1.64^{\mathrm{abc}}$ & 1.75 & $1.64^{\mathrm{abc}}$ & $93.3^{\mathrm{ab}}$ & $405.5^{\mathrm{ab}}$ \\
\hline LP & $31.2^{\mathrm{c}}$ & $67.6^{\mathrm{ab}}$ & 108 & $68.9^{\mathrm{b}}$ & $40.6^{\mathrm{b}}$ & 112 & 190 & 114 & $1.31^{\mathrm{ab}}$ & $1.65^{\mathrm{abc}}$ & 1.76 & $1.66^{\mathrm{abc}}$ & $94.3^{\mathrm{ab}}$ & $399.1^{\mathrm{ab}}$ \\
\hline LE & $30.5^{\mathrm{abc}}$ & $67.4^{\mathrm{ab}}$ & 107 & $68.4^{\mathrm{b}}$ & $40.7^{\mathrm{b}}$ & 113 & 191 & 115 & $1.34^{\mathrm{b}}$ & $1.69^{\mathrm{bc}}$ & 1.79 & $1.69^{\mathrm{c}}$ & $96.7^{\mathrm{ab}}$ & $398.2^{\mathrm{ab}}$ \\
\hline LP-LE & $29.4^{\mathrm{a}}$ & $62.5^{\mathrm{a}}$ & 98.4 & $63.4^{\mathrm{a}}$ & $39.5^{\mathrm{a}}$ & 109 & 179 & 109 & $1.35^{\mathrm{b}}$ & $1.74^{\mathrm{c}}$ & 1.82 & $1.72^{\mathrm{c}}$ & $100.0^{\mathrm{b}}$ & $375.2^{\mathrm{a}}$ \\
\hline STD+Prot 125 & $30.8^{\mathrm{bc}}$ & $70.7^{\mathrm{b}}$ & 108 & $69.9^{\mathrm{b}}$ & $40.0^{\mathrm{ab}}$ & 111 & 182 & 111 & $1.30^{\mathrm{ab}}$ & $1.57^{\mathrm{a}}$ & 1.68 & $1.59^{\mathrm{ab}}$ & $93.3^{\mathrm{ab}}$ & $418.7^{b}$ \\
\hline $\mathrm{LP}+\operatorname{Prot} 125$ & $30.6^{\mathrm{abc}}$ & $71.1^{\mathrm{b}}$ & 106 & $69.4^{\mathrm{b}}$ & $40.6^{\mathrm{b}}$ & 117 & 186 & 114 & $1.33^{\mathrm{b}}$ & $1.65^{\mathrm{abc}}$ & 1.75 & $1.65^{\mathrm{abc}}$ & $88.3^{\mathrm{a}}$ & $377.1^{\mathrm{a}}$ \\
\hline$L P+\operatorname{Prot} 200$ & $30.1^{\mathrm{abc}}$ & $71.6^{\mathrm{b}}$ & 106 & $69.3^{\mathrm{b}}$ & $40.1^{\mathrm{ab}}$ & 114 & 190 & 115 & $1.33^{\mathrm{b}}$ & $1.60^{\mathrm{abc}}$ & 1.80 & $1.66^{\mathrm{abc}}$ & $98.3^{\mathrm{ab}}$ & $419.4^{b}$ \\
\hline LE+Prot 125 & $29.7^{\mathrm{ab}}$ & $70.3^{b}$ & 108 & $69.3^{\mathrm{b}}$ & $39.7^{\mathrm{a}}$ & 117 & 191 & 116 & $1.34^{\mathrm{b}}$ & $1.67^{\mathrm{abc}}$ & 1.77 & $1.67^{\mathrm{abc}}$ & $96.7^{\mathrm{ab}}$ & $407.9^{\mathrm{ab}}$ \\
\hline $\mathrm{LE}+\operatorname{Prot} 200$ & $31.0^{\mathrm{c}}$ & $69.6^{\mathrm{b}}$ & 108 & $69.6^{\mathrm{b}}$ & $40.9^{\mathrm{b}}$ & 115 & 195 & 117 & $1.32^{\mathrm{ab}}$ & $1.66^{\mathrm{abc}}$ & 1.80 & $1.68^{\mathrm{bc}}$ & $98.3^{\mathrm{ab}}$ & $413.4^{\mathrm{ab}}$ \\
\hline LP-LE+Prot 125 & $31.2^{\mathrm{c}}$ & $69.4^{\mathrm{b}}$ & 104 & $68.3^{\mathrm{b}}$ & $41.2^{\mathrm{b}}$ & 118 & 192 & 117 & $1.32^{\mathrm{ab}}$ & $1.70^{\mathrm{c}}$ & 1.84 & $1.71^{\mathrm{c}}$ & $100.0^{\mathrm{b}}$ & $405.9^{\mathrm{ab}}$ \\
\hline LP-LE+Prot200 & $30.2^{\mathrm{abc}}$ & $69.6^{\mathrm{b}}$ & 105 & $68.2^{\mathrm{b}}$ & $39.7^{\mathrm{a}}$ & 115 & 189 & 114 & $1.32^{\mathrm{ab}}$ & $1.65^{\mathrm{abc}}$ & 1.80 & $1.68^{\mathrm{abc}}$ & $98.3^{\mathrm{ab}}$ & $407.3^{\mathrm{ab}}$ \\
\hline Pooled SEM & 0.098 & 0.46 & 0.81 & 0.32 & 0.12 & 0.61 & 1.42 & 0.58 & 0.004 & 0.008 & 0.012 & 0.007 & 0.696 & 3.46 \\
\hline
\end{tabular}

Note: Letters in superscript in a column denotes significant differences at $P<0.05$. 
Table 4. Main and interaction of crude protein/amino acid (CP/AA), apparent metabolizable energy (AME) and protease on growth performance, livability and European productivity index (EPI) of broiler chicken fed standard (STD), low protein (LP), low energy (LE), and LP-LE diets supplemented with graded level of a multi-component protease.

\begin{tabular}{|c|c|c|c|c|c|c|c|c|c|c|c|c|c|c|}
\hline \multirow[b]{2}{*}{ Source of variations } & \multicolumn{4}{|c|}{ Average daily gain (g) } & \multicolumn{4}{|c|}{ Average daily feed intake (g) } & \multicolumn{3}{|c|}{ Feed conversion ratio } & \multicolumn{2}{|r|}{ Liveability } & \multirow[t]{2}{*}{ EPI } \\
\hline & $\begin{array}{l}1-14 \\
\text { d }\end{array}$ & $\begin{array}{l}15-28 \\
\text { d } \\
\end{array}$ & $\begin{array}{l}29-42 \\
\text { d }\end{array}$ & $\begin{array}{l}1-42 \\
\text { d }\end{array}$ & $\begin{array}{l}1-14 \\
\text { d }\end{array}$ & $\begin{array}{l}15-28 \\
\text { d }\end{array}$ & $\begin{array}{l}29-42 \\
\text { d } \\
\end{array}$ & $\begin{array}{l}1-42 \\
\text { d }\end{array}$ & $\begin{array}{l}1-14 \\
\text { d }\end{array}$ & $\begin{array}{l}\text { 15-28 } \\
\text { d }\end{array}$ & $\begin{array}{l}29-42 \\
\text { d }\end{array}$ & $\begin{array}{l}1-42 \\
\text { d }\end{array}$ & $\%$ & \\
\hline \multicolumn{15}{|l|}{ Main effects: $\mathrm{CP} / \mathrm{AA}$} \\
\hline STD & 30.7 & 69.9 & 108.2 & 69.6 & 40.2 & 114.0 & 188.2 & 114.1 & 1.31 & 1.63 & 1.74 & 1.64 & 95.8 & 413.2 \\
\hline LP & 30.4 & 68.6 & 104.7 & 67.9 & 40.3 & 113.9 & 187.6 & 113.9 & 1.33 & 1.66 & 1.80 & 1.68 & 96.6 & 397.4 \\
\hline$P$ - value & 0.180 & 0.103 & 0.035 & 0.003 & 0.510 & 0.973 & 0.818 & 0.868 & 0.030 & 0.030 & 0.020 & 0.00 & 0.696 & 0.030 \\
\hline \multicolumn{15}{|l|}{ Main effects: AME } \\
\hline STD & 30.7 & 70.5 & 107.7 & 69.6 & 40.2 & 113.5 & 186.4 & 113.4 & 1.31 & 1.61 & 1.73 & 1.63 & 94.1 & 409.2 \\
\hline LE & 30.4 & 68.1 & 105.2 & 67 & 40.3 & 114.4 & 189.4 & 114.7 & 3 & 1.68 & 1.80 & 1.69 & 98.3 & 401.3 \\
\hline$P$ - value & 0.020 & 0.000 & 0.114 & 0.000 & 0.496 & 0.449 & 0.296 & 0.229 & 0.001 & 0.001 & 0.004 & 0.001 & 0.001 & 0.260 \\
\hline \multicolumn{15}{|l|}{ Main effect: Protease } \\
\hline Prot 0 & 30.5 & 67.0 & 105.8 & 67. & 40.1 & 112.2 & 188.0 & 113.4 & 1.32 & 1.68 & 1.78 & 1.68 & 96.1 & 394.5 \\
\hline Prot 12 & 30.6 & 70.4 & 106.8 & 69.2 & 40.4 & 115.6 & 187.5 & 114.5 & 1.32 & 1.64 & 1.76 & 1.65 & 94.6 & 402.4 \\
\hline Prot 200 & 30.6 & 70.5 & 106.8 & 69.3 & 40.2 & 114.1 & 188.3 & 114.2 & 1.32 & 1.62 & 1.77 & 1.65 & 97.9 & 418.8 \\
\hline \multicolumn{15}{|l|}{ Contrast $P$-value } \\
\hline Linear & 0.717 & 0.000 & 0.606 & 0.020 & 0.770 & 0.175 & 0.939 & 0.575 & 0.926 & 0.001 & 0.682 & 0.078 & 0.241 & 0.010 \\
\hline Quadratic & 0.922 & 0.059 & 0.746 & 0.203 & 0.279 & 0.051 & 0.826 & 0.566 & 0.273 & 0.718 & 0.505 & 0.516 & 0.076 & 0.560 \\
\hline \multicolumn{15}{|l|}{ Interaction $P$-value } \\
\hline CP/AA*Protease & 0.000 & 0.081 & 0.750 & 0.144 & 0.010 & 0.024 & 0.312 & 0.071 & 0.641 & 0.321 & 0.817 & 0.824 & 0.106 & 0.810 \\
\hline AME*Protease & 0.010 & 0.279 & 0.334 & 0.040 & 0.858 & 0.117 & 0.108 & 0.040 & 0.010 & 0.947 & 0.352 & 0.254 & 0.274 & 0.230 \\
\hline CP/AA*AME*Protease & 0.000 & 0.901 & 0.718 & 0.432 & 0.858 & 0.117 & 0.108 & 0.040 & 0.700 & 0.350 & 0.350 & 0.250 & 0.270 & 0.260 \\
\hline
\end{tabular}

Note: Letters in superscript in a column denotes significant differences at $P<0.05$.

The blood serum concentrations of glucose, total protein, and uric acid as well as the population of Escherichia coli, Salmonella spp. and Clostridium perfringens of broilers fed STD or low levels of CP/AA and AME diets supplemented with increasing concentrations of a protease complex are shown on Table 5. Serum glucose and uric acid concentrations were similar among the treatment groups; however, birds fed STD diets supplemented with $200 \mathrm{~g} / \mathrm{t}$ protease had significantly lower serum protein concentration as compared with birds fed LP-LE diets supplemented with $125 \mathrm{~g} / \mathrm{t}$ protease. In terms of ileal microbiota population, broilers fed LP-LE diets had significantly higher Escherichia coli, Salmonella spp., and Clostridium perfringens populations as compared to birds fed STD diets. Meanwhile, increasing protease supplementation on STD, LP, LE, and low LP-LE diets, significantly lowers Escherichia coli, Salmonella spp., and Clostridium perfringens populations.

Table 5. Serum chemicals and ileal microbiota populations in broiler chickens fed standard (STD), low protein (LP), low energy (LE), and LP-LE diets supplemented with graded level of a multi-component protease.

\begin{tabular}{|c|c|c|c|c|c|c|}
\hline \multirow{3}{*}{ Treatments } & \multicolumn{2}{|c|}{ Blood serum chemicals } & \multicolumn{4}{|c|}{ Ileal microbiota $\left(\log _{10} \mathrm{CFU} / \mathrm{g}\right)$} \\
\hline & Glucose & Protein & Uric acid & \multirow{2}{*}{ Escherichia coli } & \multirow{2}{*}{ Salmonella spp. } & \multirow{2}{*}{$\begin{array}{l}\text { Clostridium } \\
\text { perfringens }\end{array}$} \\
\hline & $\mathrm{mmol} / \mathrm{L}$ & g/dL & $\mu \mathrm{mol} / \mathrm{L}$ & & & \\
\hline STD & 8.33 & $4.98^{\mathrm{ab}}$ & 550.0 & $8.52^{\mathrm{h}}$ & $1.74^{\mathrm{a}}$ & $7.54^{\mathrm{f}}$ \\
\hline LP & 8.32 & $4.77^{\mathrm{ab}}$ & 548.9 & $7.23^{\mathrm{d}}$ & $2.29^{\mathrm{cd}}$ & $7.17^{\mathrm{e}}$ \\
\hline $\mathrm{LE}$ & 7.79 & $4.38^{\mathrm{ab}}$ & 549.9 & $8.16^{\mathrm{f}}$ & $2.09^{c}$ & $6.80^{\mathrm{d}}$ \\
\hline LP-LE & 8.03 & $4.22^{\mathrm{ab}}$ & 558.3 & $8.75^{\mathrm{i}}$ & $2.22^{\mathrm{cd}}$ & $8.29^{\mathrm{g}}$ \\
\hline STD+ Prot 125 & 8.23 & $4.16^{\mathrm{ab}}$ & 543.7 & $6.39^{c}$ & $1.85^{\mathrm{b}}$ & $6.31^{\mathrm{c}}$ \\
\hline $\mathrm{LP}+\operatorname{Prot} 125$ & 8.06 & $3.92^{\mathrm{ab}}$ & 549.9 & $7.96^{\mathrm{e}}$ & $1.60^{\mathrm{a}}$ & $6.29^{\mathrm{c}}$ \\
\hline $\mathrm{LP}+$ Prot 200 & 7.86 & $4.13^{\mathrm{ab}}$ & 549.7 & $5.87^{\mathrm{a}}$ & $2.21^{\mathrm{cd}}$ & $6.27^{\mathrm{c}}$ \\
\hline LE + Prot 125 & 8.35 & $4.38^{\mathrm{ab}}$ & 555.1 & $8.35^{\mathrm{g}}$ & $2.09^{c}$ & $5.49^{\mathrm{a}}$ \\
\hline $\mathrm{LE}+\operatorname{Prot} 200$ & 7.94 & $4.72^{\mathrm{ab}}$ & 551.7 & $6.49^{c}$ & $2.37^{\mathrm{d}}$ & $6.05^{\mathrm{b}}$ \\
\hline LP-LE + Prot 125 & 8.16 & $5.17^{\mathrm{b}}$ & 569.3 & $8.63^{\mathrm{h}}$ & $2.42^{\mathrm{d}}$ & $6.99^{\mathrm{de}}$ \\
\hline LP-LE + Prot 200 & 8.58 & $3.80^{\mathrm{ab}}$ & 537.3 & $8.56^{\mathrm{h}}$ & $2.29^{\mathrm{cd}}$ & $6.98^{\mathrm{de}}$ \\
\hline Pooled SEM & 0.130 & 0.097 & 5.170 & 0.123 & 0.032 & 0.087 \\
\hline
\end{tabular}

Note: Letters in superscript in a column denotes significant differences at $P<0.05$.

The main and interaction effects of CP/AA, AME, and protease supplementation on blood chemistry (glucose, total protein, and uric acid) and ileal microbiota population (Escherichia coli, Salmonella spp. and Clostridium perfringens) are presented in Table 6. Among the blood parameters, significant difference only existed on the main effect of protease on serum protein concentration, however, an AME x Protease and a CP/AA x AME x Protease interaction effects on this parameter were also observed. Significant differences on the main effects of $\mathrm{CP} / \mathrm{AA}, \mathrm{AME}$, and protease 
were found on Escherichia coli, Salmonella, and Clostridium perfringens populations in ileal digesta at 42-d. Reducing dietary CP/AA increased numbers of Escherichia coli, Salmonella spp., and Clostridium perfringens while protease supplementation decreased the counts of all these bacteria. Nevertheless, a CP/AA x Protease, an AME x Protease, and a CP/AA x AME x Protease interaction effects existed on these parameters.

Table 6. Main and interaction effects of crude protein/amino acid (CP/AA), apparent metabolizable energy (AME) and protease on serum chemicals and ileal microbiota populations of broiler chickens fed standard (STD), low protein (LP), low energy (LE), and LP-LE diets supplemented with graded level of a multi-component protease.

\begin{tabular}{|c|c|c|c|c|c|c|}
\hline \multirow{3}{*}{ Source of variations/treatments } & \multicolumn{2}{|c|}{ Blood serum chemicals } & \multicolumn{4}{|c|}{ Ileal microbiota $\left(\log _{10} \mathrm{CFU} / \mathrm{g}\right)$} \\
\hline & Glucose & Protein & Uric acid & Ecchorichiocoli & Salmanolla snn & Clostridium \\
\hline & $\mathrm{mmol} / \mathrm{L}$ & g/dL & $\mu \mathrm{mol} / \mathrm{L}$ & escnericnia coi & saimoneta spp. & perfringens \\
\hline \multicolumn{7}{|l|}{ Main effect: $\mathrm{CP} / \mathrm{AA}$} \\
\hline STD & 8.06 & 4.38 & 548.3 & 7.36 & 2.05 & 6.38 \\
\hline LP & 8.17 & 4.34 & 552.2 & 7.83 & 2.17 & 7.00 \\
\hline$P$-value & 0.691 & 0.820 & 0.725 & 0.000 & 0.000 & 0.000 \\
\hline \multicolumn{7}{|l|}{ Main effect: AME } \\
\hline STD & 8.09 & 4.27 & 546.9 & 7.03 & 1.98 & 6.61 \\
\hline LP & 8.14 & 4.45 & 553.6 & 8.16 & 2.25 & 6.77 \\
\hline$P$-value & 0.841 & 0.316 & 0.550 & 0.000 & 0.000 & 0.000 \\
\hline \multicolumn{7}{|l|}{ Main effect: Protease } \\
\hline Prot 0 & 8.12 & 4.59 & 551.8 & 8.16 & 2.08 & 7.45 \\
\hline Prot 125 & 8.20 & 4.41 & 554.5 & 7.83 & 1.99 & 6.27 \\
\hline Prot 200 & 8.02 & 4.07 & 544.6 & 6.78 & 2.27 & 6.34 \\
\hline Linear & 0.783 & 0.020 & 0.596 & 0.000 & 0.000 & 0.000 \\
\hline Quadratic & 0.630 & 0.685 & 0.592 & 0.000 & 0.000 & 0.000 \\
\hline \multicolumn{7}{|l|}{ Interaction $P$-value } \\
\hline CP/AA*Protease & 0.702 & 0.448 & 0.902 & 0.000 & 0.000 & 0.019 \\
\hline AME*Protease & 0.424 & 0.010 & 0.842 & 0.000 & 0.000 & 0.000 \\
\hline CP/AA*AME*Protease & 0.933 & 0.021 & 0.777 & 0.000 & 0.000 & 0.000 \\
\hline
\end{tabular}

Note: Letters in superscript in a column denotes significant differences at $P<0.05$.

\section{Discussion}

This study investigated the effects of a multi-component alkaline serine protease on performance, blood serum parameters, and ileal population of three potentially pathogenic bacteria in broiler chicken fed low protein (LP), low metabolizable energy (LE), LP-LE, and standard (STD) diets. A multicomponent protease can be defined as a protease complex where none of the component occupies more than half of the complex. The feed intake was normal and no differences among the main effects (CP/AA, AME, and protease levels). However, interaction effects of AME $\mathrm{x}$ Protease and CP x AME x Protease on feed intake were significant for 1-42 d. Liveability (1 to $42-\mathrm{d}$ ) varied between the groups $(P=0.02)$ although the reasons for mortality were non-specific. Post-mortem of the dead birds did not reveal any pathognomonic lesion and the deaths were mostly of accidental in origin. Hence, it is difficult to correlate the liveability with the dietary treatments. Though EPI was not affected by dietary AME per se, liveability was lower in the LE groups $(P=0.001)$.

In this study, the protease supplementation linearly improved ADG during 15-28 $\mathrm{d}(P=0.001)$ and $1-42 \mathrm{~d}(P=$ 0.022 ) indicating better responses with higher inclusion level of the protease. Despite significant linear improvement in ADG, most performance parameters and tested blood serum chemicals were unaffected by protease supplementation to the
LP diets except for ADG and ADFI during 1-14 days $(P<$ $0.05)$. There are mixed reports on body weight gain in broiler chickens fed low protein diets supplemented with protease. Similar to the findings of this study, Yu et al. [10] and recently, Cardinal et al. [16] reported no significant improvement in growth performance of birds fed low protein $(5 \%$ and $6 \%$ $\mathrm{CP} / \mathrm{AA}$ reduction, respectively) diets. However, Cardinal et al. [16] observed a significant reduction in FCR from 1.73 to 1.60 in birds fed the protease supplemented low CP/AA diets. In a similar study with a different protease (a mono-component protease), Dessimoni et al. [17] reported similar findings i.e. no difference in performance between the low CP/AA (10\% reduction) and the protease supplemented diets. However, when supplemented on-top of a standard diet or $<5 \%$ reduction of CP/AA, both multi-component [18, 19] and mono-component $[13,20,21]$ showed significant improvement in growth performance. It could be hypothesized that a drastic reduction in $\mathrm{CP} / \mathrm{AA}$ possibly imbalanced the amino acid profile negating the nutrient uplifting effects of dietary protease.

In this study, LE diet caused poorer FCR irrespective of the $\mathrm{CP} / \mathrm{AA}$ and protease in diets during 1 to $14-\mathrm{d}, 15$ to $28-\mathrm{d}, 29$ to $42-\mathrm{d}$ and 1 to $42-\mathrm{d}(P<0.01)$. Supplementation of protease elicited a dose dependent linear effect on FCR during 15 to 28-d $(P=0.001)$ and a significant effect of AME x Protease interaction was observed during 1 to $14-\mathrm{d}(P=0.012)$. Protease supplementation to the low AME diets significantly 
improved ADG (1-14 and 1-42 d), ADFI (1-42 d) and FCR (1-14 d). Kamel et al. [21] observed a similar trend in weight gain, ADFI and FCR in birds fed either a standard or low energy diets supplemented with a protease but no effects on low protein or low protein-low energy diets.

Lowering diet $\mathrm{CP} / \mathrm{AA}$ and $\mathrm{AME}$ did not affect serum concentrations of glucose, total protein, and uric acid in this study $(P>0.05)$. There was subtle effect of supplemental protease on serum concentrations of glucose and uric acid $(P>$ $0.05)$. However, total protein in serum decreased as the inclusion level of protease in diet increased $(P=0.02)$. Interestingly, some previous studies did not observe any reduction in serum protein level in birds supplemented with a dietary protease $[22,23]$. The protease used in this study is different than those used in the aforementioned studies and the effect on serum protein in this study perhaps augmented by significantly linear decrease in birds fed protease supplemented STD and LP diets not in those fed the LE or LP-LE diets.

The effects of exogenous protease on performance, reducing some anti-nutritional factors, and nutrient digestibility are described in numerous studies [6, 24-26] and well-summarized by Cowieson and Roos [27]. In contrast, the extra-proteinaceous effects of dietary protease are less well-understood. Some of these effects are enhanced mucin synthesis resulting in improved tight junction integrity [9], reduction in putrefaction in the gastro-intestinal tract [28], and advancement of the macro-nutrient digestion to the more proximal intestinal segments [29].

In this study, when the diets were analysed as a whole, a general trend was observed which indicated that supplementation of $200 \mathrm{~g} / \mathrm{t}$ protease to the LP and the LE diets generally decreased the number of Escherichia coli $(P<$ $0.0001)$ in the ileal digesta while for Salmonella spp. a similar effect was obtained with $125 \mathrm{~g} / \mathrm{t}$ protease $(P<0.0001)$. Protease at both the levels of inclusions decreased Clostridium perfringens numbers and the effect was more discernible in the LE diets than that in the LP diets but not with the LP-LE diets $(P<0.0001)$. Similar to this study, Park and Kim [20] and Giannenas et al. [30] reported a reduction in ileum Escherichia coli and Clostridium perfringens populations, respectively, when diets were supplemented with a protease. Although, not covered in the current study, dietary protease also reported to reduce coccidial infection in broilers [31]. Better nutrient utilization in the proximal intestine results in reduction in putrefaction in the gastro-intestinal tract exerting an starvation effect on the overall bacterial population in the hind-gut.

\section{Conclusion}

Under the conditions of this study, it can be concluded that protease supplementation sustained the harvesting biomass in the experimental birds fed lower nutrient density diets and decreased the numbers of resident bacteria in the hind gut, some of which might be potential pathogens. Hence, the study documented not only the nutrient sparing effects but also the extra-proteinaceous effect in terms of gut health of dietary protease in broiler chickens.

\section{References}

[1] Le Heurou-Luron I, Lhoste E, Wicker-Planquarl C, Dakka N, Toullec R, Corring T, et al. Molecular aspects of enzyme synthesis in the exocrine pancreas with emphasis on development and nutritional regulation. Proc. Nutr. Soc. 1993. 52: 301-313.

[2] Nir I, Nitsan Z, Mahagna M. Comparative growth and development of the digestive organs and of some enzymes in broiler and egg type chicks after hatching. Br. Poult. Sci. 1993. 34: 523-532.

[3] Parsons CM, Castanon F, Han Y. Protein and amino acid quality of meat and bone meal. Poult. Sci. 1997. 76: 361-368.

[4] Wang X, Parsons CM. Effect of processing systems on protein quality of feather meals and hog hair meals. Poult. Sci. 1997. 76: 491-496.

[5] Lemme A, Ravindran V, Bryden WL. Ileal digestibility of amino acids in feed ingredients for broilers. World Poult. Sci. J. 2004. 60: 423-437.

[6] Angel CR, Saylor W, Vieira SL, Ward N. Effects of a monocomponent protease on performance and protein utilization in 7- to 22-day-old broiler chickens. Poult. Sci. 2011. 90: 2281-2286. https://doi.org/10.3382/ps.2011-01482

[7] Apajalahti J, Vienola K. Interaction between chicken intestinal microbiota and protein digestion. Ani. Feed. Sci. Tech. 2016. 221: 323-330.

[8] Wilkie DC, Van Kessel AG, White LJ, Laarveld B, Drew MD. Dietary amino acids affect intestinal Clostridium perfringens populations in broiler chickens. Can. J. Ani. Sci. 2005. 85: 185-193.

[9] Cowieson AJ, Roos FF. Bioefficacy of a mono-component protease in the diets of pigs and poultry: a meta-analysis of effect on ileal amino acid digestibility. J. Appl. Anim. Nutr. 2014. 2: 13-21.

[10] Yu B, Wu ST, Liu CC, Gauthier R, Chiou PWS. Effects of enzyme inclusion in a maize-soybean diet on broiler performance. Ani. Feed. Sci. 2007. 134: 283-294. http://dx.doi.org/10.1016/j.anifeedsci.2006.09.017

[11] Zuo J, Ling B, Long L, Li T, Lahaye L, Yang C, et al. Effect of dietary supplementation with protease on growth performance, nutrient digestibility, intestinal morphology, digestive enzymes and gene expression of weaned piglets. An. Nut. 2015. 1: 276-282.

[12] Tactacan GB, Oh S, Cho JH, Kim IH. Performance responses, nutrient digestibility, blood characteristics, and measures of gastrointestinal health in weanling pigs fed protease enzyme. Asian-Australas. J. Anim. Sci. 2016. 7: 998-1003.

[13] Cowieson AJ, Toghyani M, Kheravii SK, Wu SB, Romero LF, Choct M. A mono-component microbial protease improves performance, net energy, and digestibility of amino acids and starch, and upregulates jejunal expression of genes responsible for peptide transport in broilers fed corn/wheat-based diets supplemented with xylanase and phytase. Poult. Sci. 2019. 98: 1321-1332. 
[14] Saleh AA, Dawood MM, Badawi NA, Ebeid TA, Amber KA, Azzam MM. Effect of supplemental serine-protease from Bacillus licheniformis on growth performance and physiological change of broiler chickens. App. Ani. Res. 2020. 48: 86-92.

[15] Muthusamy N, Haldar S, Ghosh TK, Bedfor MR. Effect of hydrolysed Saccharomyces cerevisiae yeast and yeast cell wall components on live performance, intestinal histomorphology and humoral immune response of broilers. Brit. Poult. Sci. 2011. 52: 694-703.

[16] Cardinal KM, De Moraes ML, Andretta I, Schirmann GD, Belote BL, Barrios MA, et al. Growth performance and intestinal health of broilers fed a standard or low-protein diet with the addition of a protease. R. Bras. Zootec. 2019. 48: 1-11. https://doi.org/10.1590/rbz4820180232

[17] Dessimoni GV, Dalolio FS, Moreira J, Teixeira LV, Bertechini AG, Hermes RG. Protease supplementation under amino acid reduction in diets formulated with different nutritional requirements for broilers. Braz. J. Poult. Sci. 2019. 21 (1): 1-8.

[18] Al-juboori J. Effect of protease supplementation in broiler feed on growth performance, carcass yield and total nitrogen retention in fecal matter and litter. M. Sc. Thesis. 2017. Stephen S. Austin University. 2017. Available from: https://scholarworks.sfasu.edu/etds/142/

[19] Taelibhong M, Attamangkune S, Ruangpanit Y. Effect of using alternative protein feedstuffs with protease supplementation in diet on growth performance and apparent ileal protein digestibility of broilers. Mahanakorn Vet. Med. 2019. 14: 93-104.

[20] Park JH, Kim IH. Effects of a protease and essential oils on growth performance, blood cell profiles, nutrient retention, ileal microbiota, excreta gas emission, and breast meat quality in broiler chicks. Poult. Sci. 2018. 97: 1854-2860.

[21] Kamel NF, Raaga NM, El-Banna RA, Mohamed FF. Effects of a monocomponent protease on performance parameters and protein digestibility in broiler chickens. Agri. Agrisci. Proc. 2015. 6: 216-225. https://doi.org/10.1016/j.aaspro.2015.08.062

[22] Naik RP, Reddy AR, Reddy KK, Jyothi J. Effects of encapsulated protease enzyme on the performance, carcass, serum protein and retention of protein and energy in broilers. Int. J. Livest. Res. 2017. 7: 220-227.
[23] Law FL, Zulkifli I, Soleimani AF, Liang JB, Awad EA. The effects of low-protein diets and protease supplementation on broiler chickens in a hot and humid tropical environment. Asian-Australas. J. Anim. Sci. 2018. 31: 1291-1300.

[24] Barekatain MR, Antipatis C, Rodger N, Walkden-Brown SW, Iji PA, Choct M. Evaluation of high dietary inclusion of distillers dried grains with solubles and supplementation of protease and xylanase in the diets of broiler chickens under necrotic enteritis challenge. Poult Sci. 2013. 92: 1579-1594.

[25] Cowieson AJ, Zaefarian F, Knap I, Ravindran V. Interactive effects of dietary protein concentration, a mono-component exogenous protease and ascorbic acid on broiler performance, nutritional status and gut health. Anim. Prod. Sci. 2016. 57: 1058-1068. https://doi.org/10.1071/AN15740

[26] Yan F, Dibner JJ, Knight CD, Vazquez-Anon M. Effect of carbohydrase and protease on growth performance and gut health of young broilers fed diets containing rye, wheat, and feather meal. Poult. Sci. 2017. 96: 817-828.

[27] Cowieson AJ, Roos FF. Toward optimal value creation through the application of exogenous mono-component protease in the diets of non-ruminants. Ani. Feed. Sci. Tech. 2016. 221: 331-340.

[28] Windey K, De Preter V, Verbeke K. Relevance of protein fermentation to gut health. Mol. Nutr. Food Res. 2012. 56: 184-196.

[29] Liu SY, Selle PH, Court SG, Cowieson AJ. Protease supplementation of sorghum-based broiler diets enhances amino acid digestibility coefficients in four small intestinal sites and accelerates their rates of digestion. Anim. Feed Sci. Technol. 2013. 183: 175-183. https://doi.org/10.1016/j.anifeedsci.2013.05.006

[30] Giannenas I, Bonos E, Anestis V, Filioussis G, Papanastasiou $\mathrm{DK}$, Bartzanas $\mathrm{T}$, et al. Effects of protease addition and replacement of soybean meal by corn gluten meal on the growth of broilers and on the environmental performances of a broiler production system in Greece. PLoS ONE. 2017. 12 (1): e0169511. doi: 10.1371/journal.pone.0169511.

[31] Peek HW, Van Der Klis JD, Vermeulen B, Landman WJM. Dietary protease can alleviate negative effects of a coccidiosis infection on production performance in broiler chickens. Anim. Feed Sci. Technol. 2009. 150: 151-159. 